\title{
DNA-encoded chemical libraries
}

\section{Doctoral Thesis}

\section{Author(s):}

Dumelin, Christoph Erich

Publication date:

2007

Permanent link:

https://doi.org/10.3929/ethz-a-005416328

Rights / license:

In Copyright - Non-Commercial Use Permitted 
DISS. ETH NO. 17179

\section{DNA-Encoded Chemical Libraries}

A dissertation submitted to the

ETH Zurich

for the degree of

Doctor of Sciences

presented by

Christoph Erich Dumelin

Dipl. Natw. ETH

born 12.04.1979

citizen of Hüttlingen (TG)

accepted on the recommendation of

Prof. Dr. Dario Neri, examiner

Prof. Dr. Karl-Heinz Altmann, co-examiner

Zurich, 2007 


\section{Summary}

The discovery of molecules capable of binding to target proteins with both high affinity and specificity is a formidable task in chemistry and pharmaceutical sciences. Recently developed technologies based on the linkage of phenotype and genotype (e.g., phage display) enable the rapid isolation of binding molecules with the desired properties and have contributed to the growth of the market of biopharmaceuticals in the pharmaceutical industry. However, these methodologies are limited to the discovery of peptide-based molecules. To apply the linkage of phenotype and genotype to small organic molecules we have covalently coupled compounds to oligonucleotides. The oligonucleotides carry a coding domain encoding for the small organic molecule attached to it and a hybridization domain to pair one DNA-encoded chemical library with a second. Thereby, large libraries are generated rapidly and bivalent interactions with the target protein become possible. These libraries can be used in panning experiments to identify binding moieties to the target protein.

In the first part of this thesis we have elucidated the influence of bivalent interactions based on DNA-scaffolds on binding affinity and the impact on selection procedures. Using the streptavidin-iminobiotin interaction as a model system we demonstrated that molecules presented bivalentely on DNA experience a strong increase of affinity over the monovalent binding. Furthermore, this increased affinity gives rise to an enrichment in selection experiments. Replacing the DNA moiety with a suitable low molecular weight scaffold resulted in a small molecule capable of binding to streptavidin with high affinity.

Encouraged by these results a larger library of oligonucleotide-compound conjugates was synthesized and characterized. The quality of the library and the robustness of the selection and read-out procedure were validated by performing a series of panning experiments against streptavidin. This resulted in the reproducible identification of one high- and two low-affinity binding molecules thus verifying the functionality of the technology.

In a second selection experiment binding molecules to human serum albumin were sought. This led to the identification of a class of portable albumin binding molecules. Characterization of the interaction revealed the binding affinities of the individual 
compounds to be in the micromolar range. Conjugation of the compound with the highest affinity to fluorescein and to a gadolinium chelator, two contrast agents commonly applied for angiographic studies, gave rise to conjugates with similar affinities to serum albumin. Upon i.v. injection these conjugates demonstrated improved pharmacokinetic behavior in mice. The binding of the contrast agents to serum albumin increased the half-life in blood and decreased the extravasation into the tissues, thus enabling longer measurement times and resulting in better contrastto-noise ratios. The improved performance of the derivatives of the contrast agents was demonstrated in mice by fluorescein angiographic studies of the eye fundus and magnetic resonance images of the head.

The identified molecules are of clinical interest since the binding affinities to serum albumin of mice and humans are comparable. Albumin binding is not influenced by the conjugation to molecules of interest, thus facilitating the portability of the binding compounds and enabling the improvement of pharmacokinetic behavior of other molecules. 


\section{Zusammenfassung}

Die Identifizierung von Molekülen, welche sowohl mit hoher Affinität als auch Spezifität an ein gewünschtes Zielprotein binden, ist ein zentrales Problem in der Entwicklung von neuartigen Medikamenten. Einige der im letzten Jahrzehnt erarbeiteten Methoden (z.B. Phage-Display) ermöglichen zwar die Selektion von Bindern aufgrund der Verknüpfung von Genotyp und Phänotyp, sind aber beschränkt auf Binder, die auf natürlichen Aminosäuren basieren. Um diese Limitierung aufzuheben und Selektionen auf den Bereich kleiner organischer Moleküle auszudehnen, haben wir solche Moleküle an Oligonukleotide geknüpft. Die Oligonukleotide bestehen aus einer Kodierungsdomäne, welche die Identifikation des gekoppelten Moleküles erlaubt, sowie einer Hybridisierungsdomäne, mit deren Hilfe zwei DNA-kodierte Bibliotheken kombiniert werden können, was eine exponentielle Vergrösserung der Bibliothek ermöglicht. Bibliotheken dieser Art können für die Selektion von kleinen organischen Bindern verwendet werden.

Zu Beginn dieser Doktorarbeit haben wir den Einfluss von bidentaten Interaktionen auf die Bindungsaffinität und das Ergebnis von Selektionsexperimenten untersucht. Die Untersuchung der Bindung von Iminobiotin an Streptavidin zeigte, dass die Affinität von bivalenten Bindern gegenüber monovalenten Bindern stark erhöht ist und sich diese Affinitätsverbesserung in Selektionsexperimenten in einer Anreicherung bivalenter Binder widerspiegelt. Desweiteren konnten wir zeigen, dass sich die DNA als Gerüst für bivalente Interaktionen durch geeignete niedermolekulare Rückgrate ersetzen lässt, wodurch ein ähnlicher Affinitätsgewinn verzeichnet werden kann.

Aufgrund dieser Ergebnisse haben wir eine grössere Bibliothek von OligonukleotidKonjugaten kleiner organischer Moleküle synthetisiert und charakterisiert. Die reproduzierbare Identifizierung von nieder- und hochaffinen Streptavidin-Bindern in mehreren Testselektionen unterstrich die Qualität der Bibliothek und die Funktionalität der Dekodierungsmethodik.

In einer weiteren Selektion wurde eine Klasse von bislang unbekannten Bindern an humanes Serumalbumin entdeckt. Die Charakterisierung der identifizierten Moleküle zeigte eine Affinität im unteren bis mittleren mikromolaren Bereich. Kopplung des 
Albuminbinders mit der höchsten Affinität an Fluorescein und einen GadoliniumChelator, zwei angiographische Kontrastmittel, führte zu einem kinetisch stabilen Komplex zwischen Kontrastmittel und Serumalbumin. Pharmakokinetische Studien in Mäusen zeigten, dass die Konjugate eine verlängerte Halbwertszeit und eine reduzierte Extravasation ins Gewebe aufweisen. Dies ermöglicht längere Aufnahmezeiten und ergibt ein besseres Kontrast-Rausch-Verhältnis. Die verbesserte Bildgebung der Kontrastmittel wurde in Mäusen mittels Fluoresceinangiographie des Augenfundus und Kernspinresonanztomographie des Kopfes demonstriert.

Die identizierten Albuminbinder sind von klinischer Relevanz, da die Affinitäten zu murinem und humanem Serumalbumin vergleichbar sind und daher ähnliche Effekte auf die Pharmakokinetik im Menschen erwartet werden dürfen. Da die Bindung an Albumin nicht von dem zu konjugierenden Molekül abhängt, kann der Binder als übertragbare Einheit das pharmakokinetische Verhalten einer Reihe von pharmazeutisch relevanten Molekülen beeinflussen. 